\title{
Self-Regulation of Emotion as an Alternative to Reduce Student's Aggressiveness
}

\author{
Purwadi, S. Alhadi \& S.Muyana \\ Universitas Ahmad Dahlan \\ Yogyakarta, Indonesia \\ said.alhadi@bk.uad.ac.id
}

\begin{abstract}
This study aims to provide an overview of selfregulation of emotion that can be used as an alternative solution to reduce the aggressive behavior of students. The design of this study is the study of literature with the type of descriptive qualitative research. The analysis is done descriptively by examining the various literature that can be used as the basic foundation. Sources of data used in this study in the form of primary data sources, namely journals and books. The results of the analysis show that aggressive behavior among students arises because there are failures in controlling the emotions and behavior of individuals. Some of the things that affect the regulation of the individual's emotions are related to how the individual performs an emotional assessment, emotional setting, and emotional disclosure. Therefore, the proper self-regulation of emotion needs to be developed so that students can avoid aggressive behavior.
\end{abstract}

\section{Keywords—self-regulation, emotion, aggressiveness}

\section{INTRODUCTION}

The rise of cases of a brawl between students in Indonesia is an example of aggressive behavior among students which cannot be reduced optimally. A study done by Suhertina (2003) showed that gang fight among students in a big city lead to a criminality; otherwise the police are needed to overcome it. Besides that, students also bring weapons in that gang fight, they even do not doubt to kill their opponents. The result of a study conducted by Firdaus (2013) showed that $33 \%$ of 146 students in a junior high school in Surabaya behave aggressively. This condition showed that there are some amount of students with high aggressiveness who do not doubt to harm others, which means those students do not have a good ability to regulating their emotion. Elliott (in Tremblay \&Cairns, 2000) found that a number of violence to boys and girls in 12 until 17 years old are escalated.

Aggressive behavior can be showed by every individual even they are still a baby, pre-school age, adolescence, and adults. Aggressive behavior can continue to adulthood. Baron and Byrne (2004) stated that aggressiveness can be possessed by every individual. Yet its developments are affected by a various individual or environmental factors. Individually, natural character of an individual determines their reaction when facing the certain situation. Besides, one of many factors that trigger aggressive behavior is their failure to regulating their emotion and behavior. Aggressive behavior consistently showed the lack of interpersonal ability in emotion management and planning.

Rahayu (Guswani and Kawuryan, 2011) stated that aggressive behavior comes up easier in the emotional and unstable individual. Individuals with high emotional maturity level are able to minimize aggression encouragement and control their emotion, good at reading others' feeling, also keep good relation with their environment. So if someone has the good emotional maturity, he will be able to control his aggressive behavior. Hurlock (1994) stated that good emotional and maturity of individuals can be identified as individuals who are able to critically assess a situation before deciding to do something, able to keep them from behaving without think first. Therefore, the emotional self-regulation needs to be increased so that students can avoid aggressive behavior. Emotional self-regulation is a way to control and regulate emotions, including aggressive emotions. Students who have self-regulation of bad emotions are at risk of having a tendency to be the offender in hurting others. The results of this analysis aim to provide an overview of emotional settings that can be used as an alternative solution to reduce the students' aggressive behavior.

\section{METHOD}

This research is a descriptive qualitative research using literature study design. This study examines the self-regulation of emotion as an alternative solution to reduce the aggressive behavior of students through primary data source, like journals and books. The data collected was in the form of text data from journals and books relevant to the variables discussed in this study. The instrument in this study is a researcher himself. Data analysis by means of content analysis is done by connecting, comparing, interpreting and concluding content from various data text used.

\section{RESULTS AND DISCUSSION}

Aggressive behavior is defined as an action that is done in order to harm other people physically or psychologically (Berkowitz, 1995; Myers, 2002). Aggressive behavior tends to cause anger for others and destruct other people' belonging (Franzoi, 2003; Anderson \& Huesmann, 2003). Aggressive behavior which is not well-controlled leads to disharmony to society' norm and values, it also makes that individual get the problem with his social environment. 
Individuals' aggressive behavior can be recognized through several characteristics that suggested by Anantasari (2006), namely: (a) Striking behavior; this behavior emphasizes of someone' action that hurt feeling or destructing other people' things, and socially unaccepted;(b) Behavior that hurt themselves, other people, or other objects as a substitute; (c) Behavior that is unaccepted by their targets; commonly, aggressive behaviors have a characteristic that is unaccepted by a person who becomes the target of the behavior; (d) Behavior that violates social norms; Aggressive behavior commonly related to social norms violation. (e) Adversative Attitude with others; aggressive behavior that refers to adversative attitude as an action which is done to hurt other people; (f) Learnt Aggressive Behavior; aggressive behavior that is learned through past experience, in learning aggressive behavior, various social or environmental conditions encourages it to blown up.

Aggressive behavior consists of various forms that can be recognized based on its characters. According to Masykouri (2005), aggressive behavior can be in the form of verbal and nonverbal terms. The verbal aggressive behavior usually depends on the situation, while non-verbal aggressive behavior is a response to frustration, fear, or anger situation, which is done through an attempt to hurt other people. Dominant forms of aggressive behavior are punching, fighting, mocking, shouting, refusing an order, crying, and destructing. Related to types of aggressive, White, Jarrett, and Olledick (2012) stated that there is the difference between reactive and proactive functional aggression subtype. Reactive aggression is a defensive response or revenge that affects provocation or threat notion, while proactive aggression is a behavior done without provoking or angry to obtain the wanted purpose (Dodge and Coie 1987; Winstok 2009). Reactive aggression is in line with the learning theory of Bandura, which encouraged by external reinforcement and related with friends in the same age. In social learning theory, aggressiveness appears since there is a learning process to a certain object. Then that learning process will whether or not be repeated depends on the given reinforcement (reward or punishment). Besides, Aggressive behavior can also be formed since there is behavior imitation process to a model, or it is usually can be called as modeling. White, Jarrett, and Olledick (2012) also stated that, compared to proactive aggression, reactive aggression is more often related to psychosocial inability, including internalizing problems and attentiondeficit/ hyperactivity disorder (ADHD), while proactive aggression is more often related to mischief and callous and unemotional (Card andLittle2006; Marsee and Frick, 2007).

Reactive aggression is also related to self-regulation difficulty, including emotion disregulation. According to Buss and Perry (1992), there are four aspects of behavior that based on three basic dimensions namely motoric, effective, and cognitive. What is meant by four aspects of aggressive behavior are: (a) Physical aggression, it is aggression action that intends to hurt, disturb or endanger other people through motoric response in physical forms such as punching or kicking; (b) Verbal aggression, it is aggression action that intends to hurt, disturb, or endanger other people in form of rejection through verbal response; (c) Anger is negative emotion that is caused by unachieved expectation. The form of its expression can be in form of hurting others and also themselves. Several forms of anger are mad, upset, resentful, and how to control it includes irritability, temperamental, tend to easily upset, and anger control difficulty; (d) Hostility, it is an action that expresses hatred, enmity, antagonism, or anger to other people. Hostility is in a form of aggression that classified as a covert aggression (unseen). Hostility represents a cognitive component that consists of hatred such as jealousy and envy to other people, and being suspicious such as distrust and worries.

Rimm (2003) stated that aggressive behavior occurs because of: violence victims, being too pampered, television, video game, parents' disharmony, anger, allergy and disease, and frustration. In addition, Baron and Byrne (2005) stated that aggression occurs because of many factors such as social, personal characteristics, and situational factors. Aggressive behavior closely related to self-ability in regulating the emotion. The failure or success of emotion regulation will then affects in interpersonal ability.

In general, individuals' emotion and behavior disruption are inability that showed through the emotional response to the different behavior of their age, culture, or social norms. Aggressive behavior is one of them. It happens since a part of emotion is used as an instrument to evaluate their readiness in interacting with the environment. The ability to regulate themselves and emotion in preceding period follows to the next period. That opinion is in line with Boyer (2009), he stated that in achieving self-regulation and rules ability for children bring significant effect to their ability in regulating themselves in the future (adulthood).

Kopp (Boyer, 2012) described that self-regulation is the ability to obey orders, starting and ending situational activity, modulating intensity, frequency, and verbal and motoric movement duration in social and educational scope, delaying an action based on desired purpose or target, and generating a socially approved behavior without external supervision. Regulation of emotion emphasized on an internal factor that is able to affect external behavior such as their response and purpose in order to gain systematic target achievement. Effective self-regulation partially depends on cognitive process function that direct behaviors, solve the problem effectively, and achieve the target through guiding, directing, and regulating emotion, behavior, and other mental processes (Seguin and Zelazo 2005; Stuss and Benson 1987; Welsh and Pennington 1988). Gross and John (2003) suggested that regulation of emotion is a thinking or warning that is affected by individuals' emotion, how they experience and express it. Their thinking and behavior are greatly affected by their emotion. When they are in a negative emotion, they tend to have inability to think clearly and behave poorly.

Reivich and Shatte (2002) stated that there are two important things related to regulation of emotion, calming and focusing. Individuals who able to manage this ability are able to ease the negative emotion, focus on the disturbing thought and minimizing stress, so they could avoid inappropriate behavior that breaks the society' norms. Cole, Martin, and Dennis (2004) stated that regulation of emotion is not defined 
by activated emotion, indeed systematic change that related to activated emotion does. So, it proves that someone angrier than others does not show that the first person regulates anger differently from the second ones. The term regulation of emotion shows two types of regulation phenomena, emotion as regulation and regulated emotion. According to Thomson Cole, Martin, and Dennis (2004) regulated emotion refers to a change which is activated by emotion. This includes the change of emotion capacity, intensity, or time. A change between those domains is closely related to the regulation of emotion.

Syahadat (2013) stated three aspects in the regulation of emotion take an important role in shaping observed behavior. There is the stimulus that causes positive or negative emotion. It can show the right behavior if individual is able to regulate their emotion. The first aspect is emotion assessment in the regulation of emotion. It trains them to realize the perceived negative emotion, identify and interpret it so they are able to response it with the proper behavior. The second aspect, regulation of emotion also affects their behavior changes to the perceived negative emotion. Regulation of emotion can be achieved through training and relaxation. The third aspect, emotion expression also affects their behavior change. Generally, children and adult will be more able to regulate their emotion when they find proper ways to express their emotion.

Basically, self-regulation of emotion belongs to every individual, yet the proportion of it is quite different. It is of course affected by many aspects; one of them is the ability to improve their self-regulation of emotion. In training selfregulation of emotion, they tend to need the help from the environment or milieu, especially their close friends so they can achieve independence in developing it. Syahadat (2013) stated that sequence of self- regulation of emotion in children begins from their dependence on an external factor such as coming from their parental aspects. The next development period, in years, children will be more able to regulate their negative emotion through their interaction with others and negotiate when facing problems; this is the sequence of regulation of emotion.

\section{CONCLUSION}

Various types of aggressive behavior among students contribute to the rising percentage of adolescents' mischief in Indonesia. The forms of aggressive are verbal, non-verbal, reactive, proactive, angry, and hostility. Aggressive behavior can be affected by motoric, effective, and cognitive aspects. Aggressive behaviors among students appear since there are many affecting factors such as individual, environmental, social, and situational factors. On the other side, failure in controlling emotion also affects their behavior. Self-regulation of emotion is a way to control and regulate emotion, including emotion that triggers aggressiveness. A student with poor selfregulation of emotion ability tends to be a victim or even an actor of violence. Based on that, self-regulation of emotion is considered as necessary in order to minimize their' aggressive behavior. Abilities that affect self-regulation of emotion are the ability to calm down and stay focus. Those two abilities then will affect them in assessing, regulating, and expressing their emotion.

\section{References}

[1] Anantasari.2006. Menyikapi Perilaku Agresif Anak. Yogyakarta: Kanisius.

[2] Anderson, C.A., \& Huesmann, L.R. 2003. Human Aggressión: A Social-Cognitive View. In Hogg, M.A., \& Cooper, J. 2003. The Sage Handbook of Social Psychology. Thousand Oaks, CA: Sage Publication.

[3] Baron, R.A., \& Byrne, D.E. 2004. Social Psychology $10^{\text {th }}$ ed. USA: Pearson.

[4] Baron, R.A., and Byrne, D.E. 2005.Psikologi Social Jilid 2. Jakarta: Erlangga.

[5] Berkowitz, L. 1995. Agresi: Sebab dan Akibatnya. Jakarta. PustakaBinamanPressindo.

[6] Boyer, W. 2009.Crossing the Glass Wall: UsingPreschoolEducators' Knowledge to Enhance Parental Understanding of Children's SelfRegulation and Emotion Regulation.Early Childhood Education Journal, 37,175-182.

[7] Boyer, W. 2012.Cultural Factors Influencing Preschoolers' Acquisition of Self-Regulation and Emotion Regulation.Journal of Research in Childhood Education, 26: 169-186.

[8] Buss, A.H \& Perry, M. 1992.The Aggression Questionnaire.Journal of Personality and Social Psychology. The American Psychological Association, Inc.

[9] Firdaus,M.T. 2013. Faktor-FaktorPenyebabPerilakuAgresifpadaSiswa di SMP KelurahanKedungAsem Surabaya.Jurnal BK UNESA, 2 (1).

[10] Franzoi, S.L. 2003.Social Psychology 3rd edition. McGraw-Hill Company.

[11] Guswani, A.M., \&Kawuryan, F. 2011.Perilaku Agresi Pada Mahasiswa Ditinjau Dari Kematangan Emosi. Jurnal Psikologi Pitutur, 1 (2).

[12] Gross, J.J.,\&John, O.P.2003.Individual Differences in Two Emotion Regulation Processed: Implications for Affect, Relationships, and Well Being. Journal of Personality and Social Psychology, 85(2): 348-362.

[13] Masykouri. 2005. Faktor Penyebab Anak Berperilaku Agresif. dalamhttp://www.BelajarPsikologi.com.

[14] Myers, D.G. 2002.Social Psychology7th edition. New York: McGraw Hill.

[15] Reivich, K., \&Shatte, A. 2002.The Resilience Factor: 7 Keys To Finding Your Inner Strength And Overcome Life's Hurdles. New York: Broadway Books.

[16] Rimm, Sylvia. 2003. Mendidikan Menerapkan Disiplin pada Anak Prasekolah. Jakarta: PT Gramedia.

[17] Suhertina. 2003. Tawuran Antar Pelajaran Peranan Guru Pembimbing. Tesis tidak diterbitkan.Padang: Universitas Negeri Padang.

[18] Syahadat, Y. M. 2013. Pelatihan Regulasi Emosi untuk Menurunkan Perilaku Agresif Pada Anak. JurnalHumanitas, 10 (1).

[19] Tremblay, R.E., \& Cairns, R.B. 2000. The Development of Aggressive Behavior During Childhood: Hat Have We Learned in the Past Century? International Journal of Behavioral Development, 24 (2), 129-141.

[20] White, B. A., Jarret, M. A., Ollendick, T. H. 2012. Self-Regulation Deficits Explain the Link between Reactive Aggression and Internalizing and Externalizing Behavior Problems in Children. Journal of PsychopatholBehav Assess, DOI 10.1007/s10862-012-9310 